\title{
V. NEGUNDO, L. CAMARA AND B. VARIEGATA PLANTS LEAF EXTRACT EXHIBIT CONSIDERABLE IN VITRO ANTIOXIDANT AND ANTICANCER ACTIVITIES
}

\author{
NUTAN BADGUJAR ${ }^{1}$, KINNARI MISTRY1* ${ }^{*}$, JAGDISH PATEL ${ }^{2}$ \\ ${ }^{1}$ Ashok and Rita Patel Institute of Integrated Study and Research in Biotechnology and Allied Sciences (ARIBAS), New Vallabh Vidyanagar, \\ 388121, Gujarat, India, ${ }^{2}$ Department of Biochemistry, P. D. Patel Institute of Applied Sciences, Changa, Anand 388421, Gujarat, India \\ Email: kinnarimistry@aribas.edu.in \\ Received: 14 Feb 2017 Revised and Accepted: 31 Mar 2017
}

\section{ABSTRACT}

Objective: The study was planned to investigate antioxidant and anticancer activities with the preliminary phytochemical analysis of methanolic extracts of Vitex negundo (V. negundo), Lantana camara (L. camara) and Bauhania variegata (B. variegata) plants leaf extracts.

Methods: Phytochemical evaluation was performed for all the extracts, as per the standard methods. In vitro antioxidant activities were performed by using DPPH (2,2-Diphenyl-1-Picrylhydrazyl), ABTS (2,2'-Azino-Bis-3-Ethylbenzothiazoline-6-Sulfonic Acid) and FRAP (Ferric reducing antioxidant power assay) method and compared with standard antioxidants. The anticancer activity of plant extract was assessed using MTT colorimetric assay.

Results: The study of preliminary phytochemical proved the existence of alkaloids, flavonoids and phenolic types of phytochemicals in high amount. Methanolic extract of $L$. camara shows minimum IC 50 value for DPPH assay $(48.75 \pm 2.34 \mu \mathrm{g} / \mathrm{ml})$ and FRAP assay $(274.66 \pm 3.65 \mu \mathrm{g} / \mathrm{ml})$. In ABTS assay B. variegata extract exhibit minimum IC 50 value $(60.48 \pm 3.01 \mu \mathrm{g} / \mathrm{ml})$. Lower the IC $\mathrm{C}_{50}$ value of extract, higher the effectiveness of the plant. Methanolic extract of all plants methanolic extracts showed anticancer activity against SH-SY-5Y cells (human neuroblastoma cell) but V. negundo was more effective against SH-SY-5Y cells with $\mathrm{IC}_{50}$ value $(209 \mu \mathrm{g} / \mathrm{ml})$ compared to remaining extracts.

Conclusion: The current finding accomplished the in vitro activities, so that plant could be a superior source of antioxidant and anticancer drugs. But further in vivo assessment was needed before adding it into the pharma industry.

Keywords: Antioxidant activity, Anticancer activity, Phytochemical screening, V. negundo, L. camara and B. variegata

(C) 2017 The Authors. Published by Innovare Academic Sciences Pvt Ltd. This is an open access article under the CC BY license (http://creativecommons.org/licenses/by/4.0/) DOI: http://dx.doi.org/10.22159/ijpps.2017v9i5.17721

\section{INTRODUCTION}

Traditional plants are essential resource of valuable drugs and continue to be extensively used to treat many diseases. Discovery of new beneficial agents from plant source has been targeted in recent years. Compounds from natural sources have the beneficial effect which attributes among others, to the elevated level of bioactive compounds [1]. The bioactive molecules known as secondary metabolites produce from different parts of plant that are involved in defense mechanism of plants. Antioxidant component contains moieties which can scavenge free radicals and have reducing power, thus it protects human body from oxidative stress [2]. Antioxidants derived from plants are less toxic, more practical and economical and hence there is emergening interest in natural antioxidants from plant origin [3]. Phenolics and flavonoids are secondary metabolites from plants acts as antioxidant and according to earlier reports they have powerful free radical scavenging activity [4]. A broad variety of antioxidants are projected to be used in the treatment of various diseases from both natural and artificial origin [5]. From the last few decades of life, incidences of many cancers have increased exponentially with time. In the human population globally over six million public die because of cancer each year, representing it to be the leading single reason of death in human population [6]. Many plant sources are used to derive anticancer medicine and about $60 \%$ of the medicines are derived from plant origin for example, camptothecin from Cuscutareflxa verma and taxol from Taxus brevifolia [7]. Plant derived drugs having low side effects cause apoptosis and cytotoxicity precise to the cancer cells. The cytotoxic effect of medicinal plants and their phyto-constituents against cancerous cell lines are the evidences of positive helpfulness of medicinal plants for diversity of ailments [8].

$V$. negundo Linn. (Family Verbenaceae) is a significant plant of the Ayurveda. All parts but leaves of $V$. negundo is generally used in the indigenous system of medicine. The leaves are used for the treatment of eye-disease, skin-ulcers, toothache, rheumatoid arthritis, and inflammation, enlargement of the spleen, gonorrhoea, and bronchitis. Against Ehrlich ascites tumor cells, V. negundo plant's leaf extract shown antiasthmatic [9] and anticancer activity [10]. L. camara Linn, (Verbenaceae) has been used to cure a broad range of diseases in many parts of the world [11]. L. camara was used to treat fevers, colds, rheumatism, asthma and high blood pressure [12]. The result of pharmacological study reported that extracts from leaves of $L$. camara showed strong antioxidant activities [13]. Bark of B. variegata (Leguminosae) is traditionally used as stimulant to cure ulcers and also useful in skin diseases. In the treatment of snake poison the roots are used as an antidote [14] This plant is also used in folklore medicine to treat several diseases [15]. The current study, therefore reports the phytochemical composition along with their antioxidant and anticancer activities from V. negundo, L. camara and B. variegata plants leaf extracts.

\section{MATERIALS AND METHODS}

\section{Plant materials}

The fresh sample of selected medicinal plant V. negundo, L. camara and B. variegata were collected in August 2013 under the supervision of a botanist from Pune, India. Then all Plant specimens were authenticated and submitted in organ form to Dr. Subhash Sadhu Deokule, Department of Botany, University of Pune, India. Authentication of all plant specimens was done using macroscopic, microscopic, histochemical and phytochemical parameters.

\section{Preparation of plant extracts}

Leaves of selected plants were collected, washed under running tap water and dried by blotting. For preparing dried powder of leaf extract, washed leaves were dried at $40^{\circ} \mathrm{C}$ in hot air oven for about 4-5 $\mathrm{d}$ and ground to make fine powder. $10 \mathrm{~g}$ of powder was taken with $100 \mathrm{ml}$ of methanol and incubated at $20^{\circ} \mathrm{C}$ for the cold 
percolation extraction. Then the methanolic extract was concentrated by rotary evaporator under reduced pressure (at 30$40{ }^{\circ} \mathrm{C}$ ) filtrate obtained was concentrated and labeled as ME (methanolic extract). Then yield was calculated for extraction method. The dried extracts were stored at $-20^{\circ} \mathrm{C}$ in airtight bottles for further studies. $10 \mathrm{mg}$ of each extracts were dissolved in $1 \mathrm{ml}$ dimethyl sulfoxide (DMSO) and were diluted with DMEM medium. Then, test solutions were sterilized using $0.22 \mu \mathrm{m}$ Syringe filters (Axiva, Scichem biotech) and used as a stock solution for further experiments.

\section{Phytochemical screening}

Phytochemical evaluation was performed for all the extracts, as per the standard methods [16].

\section{Chemicals and reagents}

Following were the chemicals used in the present study. 3-(4, 5dimethylthiazol-2-yl)-2, 5-diphenyl tetrazolium bromide (MTT), Fetal Bovine serum (FBS), Phosphate buffered saline (PBS), Dulbecco's Modified Eagle's Medium (DMEM) and Trypsin were obtained from Gibco. Dimethyl Sulfoxide (DMSO) and methanol purchased from Merk Ltd., Mumbai, India. Antibiotics were purchased from Hi-Media Laboratories Ltd., Mumbai.

\section{Antioxidant activity}

\section{DPPH free radical scavenging activity}

Required quantity of trolox was dissolved in methanol and stock solution of the sample was prepared by dissolving $10 \mathrm{mg}$ of dried methanolic extract in $1 \mathrm{ml}$ of methanol to give a concentration of 10 $\mathrm{mg} / \mathrm{ml}$. The $1.5 \mathrm{ml}$ DPPH solution was added to $3 \mathrm{ml}$ methanol and for control reading at the $517 \mathrm{~nm}$ absorbance was taken immediately. Different concentration of test sample was added and made $2 \mathrm{ml}$ using methanol for dilution. Then $1.5 \mathrm{ml}$ DPPH solution was added to each test tube. Using UV-visible spectrophotometer absorbance was taken at $517 \mathrm{~nm}$ after $15 \mathrm{~min}$. Methanol was used as blank. The free radical scavenging activity (\%) was measured using the following formula:

$\%$ DPPHscavengingactivity(\%)

$$
=\frac{\text { Control absorbance }- \text { sample absorbance } \times 100}{\text { Control absorbance }}
$$

\section{ABTS assay}

The ABTS assay was performed according to the protocol of Arnao et al., with slight modification [17]. Different quantities $(10,20,40,80$ and $100 \mu \mathrm{g}$ ) of the phyto-extracts were tested. Absorbance was taken at $734 \mathrm{~nm}$. In the ABTS assay, $\mathrm{IC}_{50}$ values for the percentage of ABTS radical scavenging were calculated.

$\%$ ABTS scavenging activity(\%)

$$
=\frac{\text { Control absorbance }- \text { sample absorbance } \times 100}{\text { Control absorbance }}
$$

\section{FRAP assay}

Antioxidant activity was determined according to the method by Yusufoglu et al. [18]. $2.5 \mathrm{ml}$ of $0.2 \mathrm{M}$ phosphate buffer ( $\mathrm{pH} \mathrm{6.6)}$ and $2.5 \mathrm{ml}$ of $1 \%$ potassium ferricynide was added to all test tubes. 100 , $200,300,400$ and $500 \mu \mathrm{g} / \mathrm{ml}$ concentration of the plant extract was used for the study. This makes a total $1 \mathrm{ml}$ of plant extract. In different eppendorf tubes $1 \mathrm{ml}$ plant extracts were added test tubes and this mixture was incubated for $20 \mathrm{~min}$ at $50{ }^{\circ} \mathrm{C}$. Then $2.5 \mathrm{ml}$ of TCA was added to all tubes and then tubes were centrifuged for 10 min at $3000 \mathrm{rpm}$. After centrifuging, $2.5 \mathrm{ml}$ of supernatant liquid was collected and $2.5 \mathrm{ml}$ of distilled water and $0.5 \mathrm{ml}$ of $\mathrm{FeCl}_{3}$ was added to all test tubes. UV absorbance was recorded at $700 \mathrm{~nm}$.

\section{Cell lines and culture medium}

SH-SY-5Y (Human neuroblastoma cell) cell culture was procured from National Center for Cell Sciences (NCCS) Pune, India. Cells were cultured in Dulbecco's Modified Eagle Medium (DMEM) supplemented with $10 \%$ inactivated FBS, 1\% (v/v) Penicillin Streptomycin solution and amphotericin $(5 \mu \mathrm{g} / \mathrm{ml})$ in a humidified atmosphere of $5 \% \mathrm{CO}_{2}$ at $37^{\circ} \mathrm{C}$ until confluent. Medium was changed after every 2-3 d. The cells were grown in $25 \mathrm{~cm}^{2}$ culture flask and all experiments were carried out in 96 well plates (Himedia).

\section{Determination of cell viability by MTT assay}

The capability of cells to endure toxic concentration is the principle behind all cytotoxicity assays. This assay is based on the theory that dead cells or their products do not reduce tetrozolium. The MTT assay depends on the mitochondrial activity per cell and amount of cells present. Mitochondrial enzyme succinate dehydrogenase cleave tetrazolium salt 3-(4, 5 dimethyl thiazole-2-yl)-2, 5-diphenyl tetrazolium bromide (MTT) into a blue colored product (formazan) [19]. $1 \times 10^{6}$ cells were plated in 96 -well plates to check the toxicity of extracts towards SH-SY-5Y (human neuroblastoma cells). After adherence of cells, the medium was removed and replaced by media having the plant extracts. In $5 \% \mathrm{CO}_{2}$ incubator the plates were incubated for $24 \mathrm{~h}$ at $37^{\circ} \mathrm{C}$. Colorimetric assay with the tetrazolium salt MTT was used to determine cell viability. Absorbance of the formed purple formazan was measured at a wavelength of $570 \mathrm{~nm}$. Results were expressed as percentage cellular viability of the extracts.

\section{$\%$ Cell viability}

$$
=\frac{\text { O. } \mathrm{D} \text { of control sample }- \text { O. D. of treated sample } \times 100}{\text { O.D of control sample }}
$$

\section{Statistical analysis}

Data represented in this study were based on means \pm standard deviation (SD) of three identical experiments done in triplicates. Statistical significance was determined by analysis of variance (ANOVA). P value $\leq 0.05$ was considered statistically significant. $L D_{50}$ value represented the concentration of the test samples that caused $50 \%$ inhibition.

\section{RESULTS}

There has been revival of great interest in medicinally important plants. This is because of increased awareness of the limitations of ability synthetic pharmaceutical products to control major diseases.

\section{Extraction yield of plant}

Table 1 show the extraction yield of different plants which was calculated using below formula. The highest yield was obtained in $V$. negundo plant and the lowest yield was obtained in B. variegata.

Yield of plant extracts (\%)

\begin{tabular}{|c|c|c|}
\hline S. No & Plant name & Yield (\%) \\
\hline 1 & V. negundo & 8.12 \\
\hline 2 & L. camara & 7.54 \\
\hline 3 & B. variegata & 5.65 \\
\hline
\end{tabular}

$=$ (weight of dried sample/weight of original sample)X100

Table 1: Extraction yield (\%) from methanolic extracts of V. negundo, L. camara and B. variegata plants leaf extracts

\section{Phytochemical analysis}

The results of the phytochemical composition of all extracts are given in table 2.
The result shows that all extracts contain alkaloids, phenol and flavanoids in high amount and saponin in moderate amount and carbohydrate in low amount. Phytosterols is present in methanolic extract of L. camara only. 
Table 2: Phytochemical analysis from methanolic extracts of V. negundo, L. camara and B. variegata plants leaf extracts

\begin{tabular}{llll}
\hline Chemical test & V. negundo & L. camara & B. variegata \\
\hline Alkaloids & & +++ & + \\
Mayer's test & +++ & - & ++ \\
Wagner's Test & ++ & + & ++ \\
Dragendorff's test & - & - & ++ \\
Carbohydrates & + & + \\
Molisch's test & + & + \\
Fehling's test & & + \\
Benedict test & - & ++ \\
Phytosterols & & \\
Salkowaski test & +++ & ++ \\
Phenols & & + \\
Ferric Chloride Test & ++ & + \\
Flavonoids & & ++ \\
Ammonia test & ++ & ++ \\
Saponins & & + \\
\hline
\end{tabular}

-= Absence, $+=$ Presence, $++=$ Moderate Presence,$+++=$ More Presence

\section{Antioxidant activity}

Given the complexity of the oxidation process and the diverse nature of antioxidants, below methods (DPPH, ABTS and FRAP) were used to evaluate the antioxidant activity of extracts from different plants.

\section{DPPH assay}

In DPPH assay, plant extracts were able to reduce the stable free radical DPPH to the yellow colour 1,1-diphenyl-2 picrylhydrazyl due to their hydrogen donating property [20]. Concentration of the sample necessary to decrease the initial concentration of DPPH by $50 \%$ ( $\left.\mathrm{IC}_{50}\right)$ under the experimental condition was calculated. A lower $\mathrm{IC}_{50}$ value denoted a higher antioxidant activity. IC $\mathrm{C}_{50}$ values of methanolic extracts of $L$. camara, B. variegata, $V$. negundo leaves and standard trolox were $48.75 \pm 2.34 \mu \mathrm{g} / \mathrm{ml}, 68.94 \pm 3.12 \mu \mathrm{g} / \mathrm{ml}, 309.71 \pm 1.23 \mu \mathrm{g} / \mathrm{ml}$ and $14.26 \mu \mathrm{g} / \mathrm{ml}$, respectively (fig. 1). A lower $\mathrm{IC}_{50}$ value denoted a higher antioxidant activity.

\section{ABTS assay}

A concentration-dependent assay was carried out with the methanolic extracts of selected plants and the results are presented in (Fig.2). The $\mathrm{IC}_{50}$ value of plants in the order: BHA (8.68)>B. variegata $\quad(60.48 \pm 3.01)>L$. camara $\quad(70.43 \pm 2.48)>V$. negundo $(72.15 \pm 2.32)$ respectively. The scavenging effect was increased with increasing concentration. These results present a direct association of the antioxidant activity with BHA.

\section{Ferric-reducing activity}

The FRAP antioxidant activity was employed to determine the reducing potential of methanolic extract of selected plants. The $\mathrm{IC}_{50}$ value of the $V$. negundo, $L$. camara and $B$. variegata leaves methanolic extract was mentioned in table 3. BHA was used as a standard. There is a direct relationship between the methanolic concentration of plant extract, BHA and reducing power, where the increase of concentration of plant extract and BHA causes an increase in the reducing capacity (fig. 3).

\section{Cytotoxicity assay}

Methanolic extract of $V$. negundo, L. camara and B. variegata leaves were tested on SH-SY-5Y cells at different concentration $(500,400$, $300,200,100$ and $50 \mu \mathrm{g} / \mathrm{ml}$ ). Cytotoxicity was concentration dependent for SH-SY-5Y cells. The highest cytotoxicity was observed in methanolic extract of $V$. negundo followed by $L$. camara and B. variegata. IC 50 value for $V$. negundo was $(209 \mu \mathrm{g} / \mathrm{ml})$ followed by L. camara $(273.64 \mu \mathrm{g} / \mathrm{ml})$ and B. variegata $(318$ $\mu \mathrm{g} / \mathrm{ml}$ ) (fig. 4).
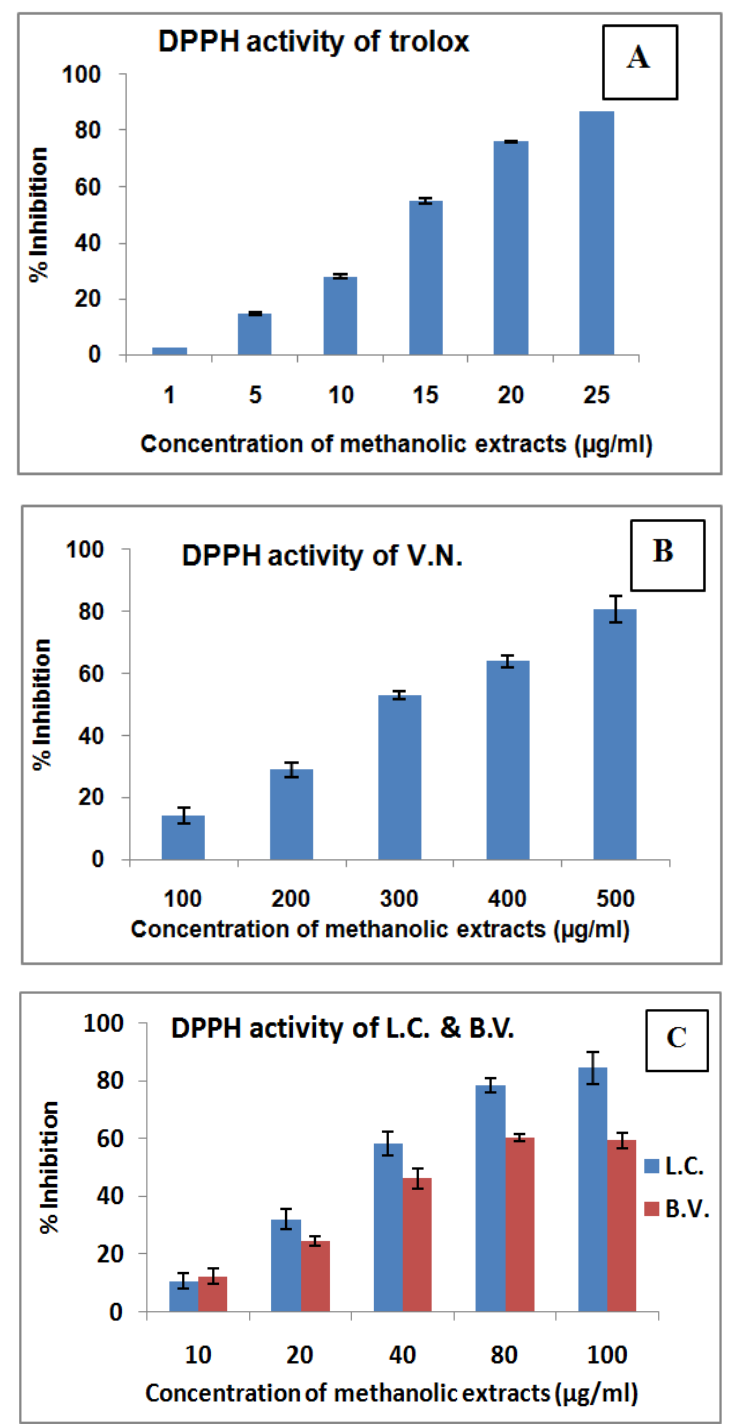

Fig. 1: (A) DPPH scavenging activity of Trolox used as standard. (B) DPPH scavenging activity from methanolic extract of $V$. negundo (V. N.). (C) DPPH scavenging assay from methanolic extracts of L. camara (L. C.) and B. variegata (B. V.). The results are expressed as mean $\pm S D$ of three replicates 


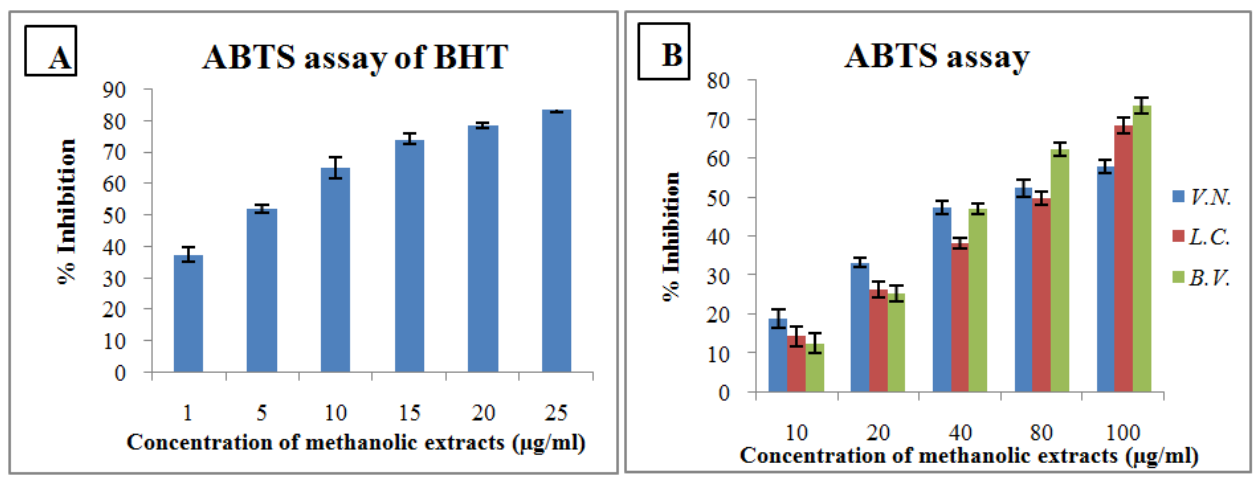

Fig. 2: (A) ABTS activity of standard BHT. (B) ABTS activity from methanolic extracts of the V. negundo (V. N.), L. camara (L. C.) and B. variegata (B. V.). Results are expressed as mean \pm SD of three replicates

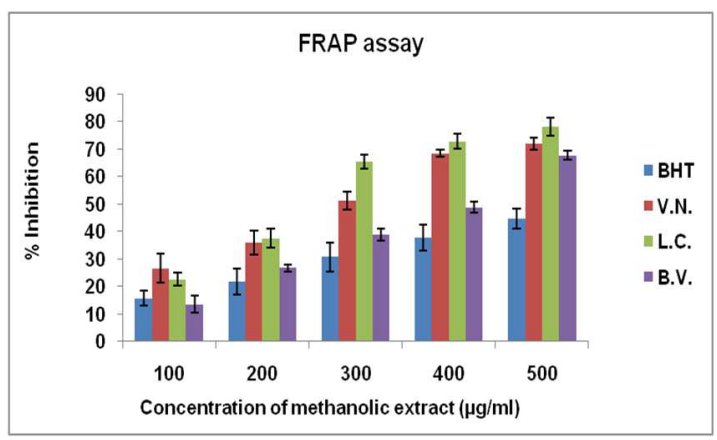

Fig. 3: FRAP activity from methanolic extracts of the V. negundo (V. N.), L. camara (L. C.), B. variegata (B. V.) and standard BHT. The results are expressed as mean $\pm \mathrm{SD}$ of three replicates

Table 3: Antioxidant effect of methanolic extract of selected plants

\begin{tabular}{|c|c|c|c|}
\hline Plants name & $\begin{array}{l}\text { DPPH } \\
\text { IC } 50 \text { value }(\mu \mathrm{g} / \mathrm{ml})\end{array}$ & $\begin{array}{l}\text { ABTS } \\
\text { IC } 50 \text { value }(\mu \mathrm{g} / \mathrm{ml})\end{array}$ & $\begin{array}{l}\text { FRAP } \\
\text { IC } 50 \text { value }(\mu \mathrm{g} / \mathrm{ml})\end{array}$ \\
\hline V. negundo & $309.71 \pm 1.23$ & $72.15 \pm 2.32$ & $303.2 \pm 1.95$ \\
\hline L. camara & $48.75 \pm 2.34$ & $70.43 \pm 2.48$ & $274.66 \pm 3.65$ \\
\hline B. variegata & $68.94 \pm 3.12$ & $60.48 \pm 3.01$ & $384.4 \pm 3.14$ \\
\hline Standard & Trolox $=14.26$ & $\mathrm{BHT}=8.68$ & $\mathrm{BHT}=548.48$ \\
\hline
\end{tabular}

Values are expressed as mean $\pm \mathrm{SD}, \mathrm{IC}_{50}$ value of methanolic extracts of plants for various antioxidant systems with respective standard. Each value represents mean value \pm SD of triplicate samples analysis, SD: standard deviation.

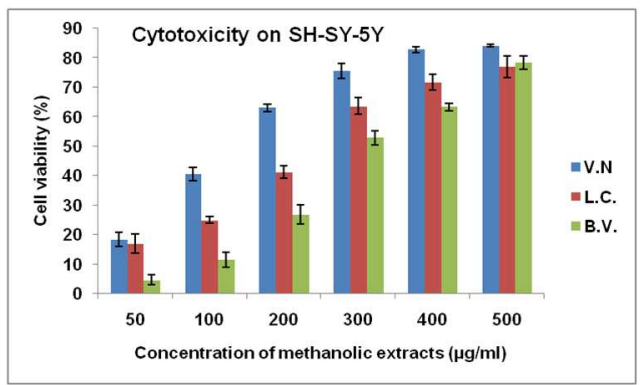

Fig. 4: Cytotoxicity activity from methanolic extracts of the $V$. negundo (V. N.), L. camara (L. C.) and B. variegata (B. V.) against SH-SY-5Y cells. Cells were incubated for $24 \mathrm{~h}$ with various concentrations of methanolic extracts of selected plants. Cell proliferation was examined using MTT assay. All experiments performed in triplicate

\section{DISCUSSION}

Plants are known to possess pharmacological activities and persist to serve as a possible source of drugs and some plant based drugs are in extensive clinical use [21]. The present study describes the phytochemicals, antioxidant and cytotoxic activities of $V$. negundo, $L$. camara and B. variegata leaves extracts.

The phytochemical study showed the presence of alkaloids, phenolics and flavonoids, which are well-known to disclose a broad variety of biological activities like antioxidant, cytotoxic, anticancer, hepatoprotective, antimicrobial, neuroprotective, antiviral and cardioprotective, properties [22]. All these natural phytochemicals possess antioxidant activity [23-25]. Biochemical activities included antioxidant parameters such as DPPH, ABTS and FRAP activities. Plants have been thoroughly evaluated for their antioxidant potential, thereby confirming their roles as potent precursors for developing effective medicines that protect against oxidative stress [26]. For screening antioxidant activity of plant extracts, DPPH assay was most widely used method [27]. With the addition of plant extracts, DPPH was reduced to diphenylpicryl hydrazine in a concentration dependent manner. The number of available hydroxyl groups can be correlated with reduction in the number of DPPH molecules. $V$. negundo, L. camara and B. variegata plant extracts showed significantly higher inhibition percentage (stronger hydrogen donating ability). The DPPH scavenging potential of $V$. negundo, L. camara and B. variegata plant extracts might be due to its reducing actions. Reducing capacity is due to presence of 
reductase, which involved in prevention of binding of metal ions, chain initiation and radical scavenging [28].

The ABTS+chemistry implicates nonstop production of ABTS+ radical mono cation. It is converted to its radical cation by the addition of potassium per sulfate and absorbs the light at $734 \mathrm{~nm}$ [29]. ROS are also formed due to metal ion mediated oxidative stress and which leads to various diseases. Metal ion induced free radical production also leads to DNA damage and lipid peroxidation [30]. The antioxidant power of BHA was considerably more evident linking to the selected plants. According to result methanolic extracts of $V$. negundo, L. camara and B. variegata have significant free radical scavenging activity and thus shows the significant antioxidant potential. In general, the ferric-reducing test is mainly employed to see the capacity of natural antioxidant in giving an electron or hydrogen [31]. According to earlier reports, there is a direct relation between ferric-reducing ability and antioxidant potential of some secondary bioactive molecules. For that reason, it is fully believed that the maximum absorbance at $700 \mathrm{~nm}$ indicates a large reducing power [32]. FRAP assay was used to find out the reducing ability from methanolic extracts of selected plants, in which the reduction of the ferricyanide complex to the ferrous form occurred due to plant extracts. Antioxidant activity was increased when concentrations of test extracts were increased, representing concentration dependent response (fig. 3) [33]. The FRAP activity in the $V$. negundo, L. camara and B. variegata suggested the presence of richer flavonoids and phenolic phytochemicals [34]. Plant-derived compounds have been a significant resource of numerous clinically helpful anticancer drugs. These include vinblastine, the camptothecin derivatives, vincristine, topotecan and paclitaxel. Ethanolic and aqueous extract of leaves of $V$. negundo shows antitumor effect against Dalton's Ascitic Lymphoma (DAL) in Swiss Albino mice [35]. Pour et al., (2011) reported that the methanolic extract of L. camara was studied for its cytotoxicity and oral acute toxicity [36]. Against Dalton's ascetic lymphoma, leukemia and many cancer cell lines, B. variegata stem was shown to have cytotoxic activity. It was previously studied that $B$. variegata contains flvones which are extra selective against ovarian cancer cell lines [37]. Secondary molecules present in the plant might be accountable for showing anticancer effect. According to earlier reports phenolic or flvonoids interacts with proteins and other important biological pathways in the cells that make them lethal to the cell or behave as growth inhibitors [38].

\section{CONCLUSION}

The study showed that the phyto-constitutes present in plants have ability to act as antioxidant as a result of their powerful radical scavenging activities. The presence of alkaloids, phenolic and flavonoids compounds are accountable for both antioxidant and cytotoxic activities. Based on the findings of the study, it can be concluded that $V$. negundo, L. camara and B. variegata leaves have an inhibitory effect on SH-SY-5Y cells. This study has provided confirmation that $V$. negundo, L. camara and B. variegata are potential source of antioxidants and cytotoxic activities. This study provides useful information to researchers for future utilization of this plant for pharmaceutical purposes.

\section{AUTHOUR CONTRIBUTION}

All authors contributed extensively to the work presented in this paper. Nutan Badgujar designed and performed experiments, analyzed data and wrote the paper. Dr. Kinnari Mistry supervised development of work, helped in data interpretation and manuscript evaluation. Dr. Kinnari Mistry acted as corresponding author. Dr. Jagdish Patel helped in cell culture related assay.

\section{CONFLICT OF INTERESTS}

Authors declare that they do not have any conflict of interest

\section{REFERENCES}

1. Cragg GM, Grothaus PG, Newman DJ. Impact of natural products on developing new anti-cancer agents. Chem Rev 2009;109:3012-43.

2. Pandey AK, Kumar S. Antioxidant, lipo-protective and antibacterial activities of phytoconstituents present in Solanum xanthocarpum root. Int Rev Biophysical Chem 2012;3:42-7.
3. Rice-Evans C. Flavonoids and isoflavones: absorption, metabolism, and bioactivity. Free Radical Biol Med 2004; 36:827-8.

4. Dave R. In vitro models for antioxidant activity evaluation and some medicinal plants possessing antioxidant properties: an overview. Afr J Microbiol Res 2009;3:981-96.

5. Cuzzocrea S, Riley DP, Caputi AP, Salvemini D. Antioxidant therapy: a new pharmacological approach in shock, inflammation, and ischemia/reperfusion injury. Pharmacol Rev 2001;53:135-59.

6. Kaufmann SH, Earnshaw WC. Induction of apoptosis by cancer chemotherapy. Exp Cell Res 2000;256:42-9.

7. Verma M, Singh SK, Bhushan S, Sharma V, Datt P, Kapahi B, et al. In vitro cytotoxic potential of Polyalthia longifolia on human cancer cell lines and induction of apoptosis through mitochondrial-dependent pathway in HL-60 cells. Chem Biol Interact 2008;171:45-56.

8. Aisha AF, Nassar ZD, Siddiqui MJ, Abu-Salah KM, Alrokayan SA, Ismail Z, et al. Evaluation of antiangiogenic, cytotoxic and antioxidant effects of Syzygium aromaticum L. extracts. Asian J Biol Sci 2011;4:282-90.

9. Patel J, Shah S, Deshpande S, Shah G. Evaluation of the antiasthmatic activity of leaves of Vitex negundo. Asian J Pharm Clin Res 2009;5:81-6.

10. Tiwari OP, Tripathi YB. Antioxidant properties of different fractions of Vitex negundo Linn. Food Chem 2007;100:1170-6.

11. Basu S, Hazra B. Evaluation of nitric oxide scavenging activity, in vitro and ex vivo, of selected medicinal plants traditionally used in inflammatory diseases. Phytother Res 2006;20:896-900.

12. Valko M, Izakovic M, Mazur M, Rhodes CJ, Telser J. Role of oxygen radicals in DNA damage and cancer incidence. Mol Cell Biochem 2004;266:37-56.

13. Bondet V, Brand-Williams W, Berset C. Kinetics and mechanisms of antioxidant activity using the DPPH free radical method. LWT-Food Sci Technol 199;30:609-15.

14. Hussain M, Ghani A. Herbal remidies used for gastrointestinal disorders in Kaghan valley, NWFP, Pakistan. Pak J Weed Sci Res 2008;14:169-200.

15. Rao YK, Fang SH, Tzeng YM. Antiinflammatory activities of flavonoids and a triterpene caffeate isolated from Bauhinia variegata. Phytother Res 2008;22:957-62.

16. Mishra AK, Mishra A, Kehri H, Sharma B, Pandey AK. Inhibitory activity of Indian spice plant Cinnamomum zeylanicum extracts against Alternaria solani and Curvularia lunata, the pathogenic dematiaceous moulds. Ann Clin Microbiol Antimicrob 2009;8:1.

17. Arnao MB, Cano A, Acosta M. The hydrophilic and lipophilic contribution to total antioxidant activity. Food Chem 2001; 73:239-44.

18. Yusufoglu HS, Soliman GA, Abdel-Rahman RF, Abdel-Kader MS, Genaie MA, Bedir E. Antioxidant and antihyperglycemic effects of Ferula drudeana and Ferula huber-morathii in experimental diabetic rats. Int J Clin Pharmacol 2015;11:738-48.

19. Denizot F, Lang R. Rapid colorimetric assay for cell growth and survival: modifications to the tetrazolium dye procedure giving improved sensitivity and reliability. J Immunol Methods 1986;89:271-7.

20. Sowndhararajan K, Kang SC. Free radical scavenging activity from different extracts of leaves of Bauhinia vahlii Wight and Arn. Saudi J Biol Sci 2013;20:319-25.

21. Heinrich M, Bremner P. Ethnobotany and ethnopharmacy-their role for anti-cancer drug development. Curr Drug Targets 2006;7:239-45.

22. Havsteen BH. The biochemistry and medical significance of the flavonoids. Pharmacol Ther 2002;96:67-202.

23. Khatua S, Roy T, Acharya K. Antioxidant and free radicalscavenging capacity of phenolic extract from Russula laurocerasi. Asian J Pharm Clin Res 2013;6:156-60.

24. Paloi S, Acharya K. Evaluation of antioxidative activity and chemicalcomposition of ethanolic extract from Amanita vaginata (Bull.) La. m.: an in vitro study. Asian J Pharm Clin Res 2014;7:88-92.

25. B Usha, KC Pushpalatha. In vitro antioxidant activity and phytochemical screening of leaf extracts of grewia heterotricha mast. Int J Curr Pharm Res 2016;8:68-72. 
26. Rajkumar V, Guha G, Kumar RA, Mathew L. Evaluation of antioxidant activities of Bergenia ciliata rhizome. Rec Nat Prod 2010;4:38-48.

27. Nanjo F, Goto K, Seto R, Suzuki M, Sakai M, Hara Y. Scavenging effects of tea catechins and their derivatives on 1, 1-diphenyl-2picrylhydrazyl radical. Free Radic Biol Med 1996;21:895-902.

28. Rawri R, Bharathi K, Jayaveera K, Asdaq S. In vitro antioxidant profile of alcoholic extract of Coccinia grandis leaves. Int J Pharm Technol 2013;5:5434-40.

29. Kala SMJ. HPTLC finger print analysis of phytocompounds and in vitro antioxidant activity of Eugenia singampattiana Bedd. J Appl Pharm Sci 2012;2:112.

30. Kumar S, Sharma U, Sharma A, Pandey A. Protective efficacy of Solanum xanthocarpum root extracts against free radical damage: phytochemical analysis and antioxidant effect. Cell Mol Biol 2012;58:171-8.

31. Shimada K, Fujikawa K, Yahara K, Nakamura T. Antioxidative properties of xanthan on the autoxidation of soybean oil in cyclodextrin emulsion. J Agric Food Chem 1992;40:945-8.

32. Hajji M, Masmoudi O, Souissi N, Triki Y, Kammoun S, Nasri M. Chemical composition, angiotensin I-converting enzyme (ACE) inhibitory, antioxidant and antimicrobial activities of the essential oil from Periploca laevigata root barks. Food Chem 2010;121:724-31.

33. Sudan R, Bhagat M, Gupta S, Singh J, Koul A. Iron (FeII) chelation, ferric reducing antioxidant power, and immune modulating potential of Arisaema jacquemontii(Himalayan
Cobra Lily). Bio Med Res Int 2014. http://dx.doi.org/ 10.1155/2014/179865

34. Akinola AA, Ahmad S, Maziah M. Total anti-oxidant capacity, flavonoid, phenolic acid and polyphenol content in ten selected species of Zingiberaceae rhizomes. Afr J Tradit Complementary Altern Med 2014;11:7-13.

35. Dewade D, Christina A, Chidambaranathan N, Bhajipale N, Tekade N. Antitumor activity of Vitex negundo Linn. against Dalton's ascitic lymphoma. Int J Pharmtech Res 2010; 2:1101-4.

36. Pour BM, Latha LY, Sasidharan S. Cytotoxicity and oral acute toxicity studies of Lantana camara leaf extract. Molecules 2011;16:3663-74.

37. Rajkapoor B, Murugesh N, Rama Krishna D. Cytotoxic activity of a flavanone from the stem of Bauhinia variegata Linn. Nat Prod Res 2009;23:1384-9.

38. Murray B, Carter R, Imrie C, Evans S, O'suilleabhain C. Diclofenac reduces the incidence of acute pancreatitis after endoscopic retrograde cholangiopancreatography. Gastroenterology 2003;124:1786-91.

\section{How to cite this article}

- $\quad$ Nutan Badgujar, Kinnari Mistry, Jagdish Patel. V. Negundo, L. Camara and B. Variegata plants leaf extract exhibit considerable in vitro antioxidant and anticancer activities. Int J Pharm Pharm Sci 2017;9(5):227-232. 